\title{
Conference review: Water and Culture: A View from Rome, 17-18 April 2019, American Academy of Rome
}

\author{
Dr. Maria BOSTENARU-DAN, researcher \\ "Ion Mincu" University of Architectureand Urbanism, \\ Faculty of Urbanism \\ Maria.Bostenaru-Dan@alumni.uni-karlsruhe.de
}

\begin{abstract}
On 17-18 April 2019, a conference was held at the American Academy of Rome (AAR) on the topic of coupling water as a hazard (floods, illness) and water as heritage, spanning from archaic (i.e. Antiquity) to contemporary design. The talks consisted of an introduction, two full sessions, a panel session on the pressing issue of climate change, and a final discussion. ENEL was one of the event-planning partners. Various fields of study were represented, ranging from design to branches of humanities and social sciences, including economics. Speakers came mainly from the USA with research fields related to Italy. Prior to the conference, a symposium on "Designing with water" was organized by the AAR, the conclusions of which were presented in the panel.
\end{abstract}

Keywords: floods, Antiquity, rural landscapes, design, energy

\section{OVERVIEW}

"Water and culture: A view from Rome" was an international conference held this spring at the American Academy of Rome in collaboration with the ENEL foundation. The American Academy of Rome is an organisation housing artists and researchers in humanities for residences in frame of the so-called Rome prize, which the name of these fellowships. Numerous countries have similar representative entities in the international city of Rome.

The conference opened with an introduction that touched on the event's rationale. John Ochsendorf from the American Academy in Rome presented how the contributions would encompass landscape, archaeology and history, but also politics, architecture and design, including dealing with extreme events and the political framework for design. Carlo Papa from the ENEL Foundation talked about the contribution of geothermal energy against the background of rising mean summer temperatures from 32 to $36^{\circ} \mathrm{C}$, all while highlighting how much we can learn from history, and what architects, planners and experts can do in this field. What was presented at the conference will hopefully become common practice in 20 years, and this is detailed in the dedicated webpage section. (https://corporate.enel.it/en/futur-e)

\section{FIRST SESSION}

The first session was opened by Lynne Lancaster from the American Academy in Rome, who is now serving as the Andrew W. Mellon Professor-inCharge of Humanities, and who explained that the aim of the conference was to see water and culture in both historical and contemporary times. Water management is important in order to see the cultural factors that governed human decision in the past and to tackle environmental challenges of the future. Passing from heritage to hazard, the last two talks are on disruptive water.

After the introduction, the first talk in the first session was headed by Cynthia Bannon from Indiana University, a scholar in classical studies, and tackled „Roman Water Law: Aims and Assessments. Legal rights in access to water". 
Among the author's publications on the topic, there is a book titled "Gardens and Neighbors: Private Water Rights in Roman Italy (Law and Society in the Ancient World)". The speaker cited from Latona and the Lycians Ovid Metamorphosaes 6.342-3 and 6.349-51 "Why do you keep me from water" (it is common, free to all, as natural resource). Various sources for Roman Law were presented as well, such as Roman legal institutions for water, including rainwater - and the risk of damage, the special conditions on rural land; rivers and navigation, but also how the modern concept of public benefit developed (open access and the difficulty to regulate). The speaker talked about aqueducts: pont $d u$ Gard, parco degli aquaedotti, starting $312 \mathrm{BCE}$, as well as about the water flow to fountains, baths, illegal taps. An inscription found near Tivoli defines the servitude of water. Rainwater and servitude mean private water. Rivers and aqueducts mean public water.

The second talk was given by Kathy Gleason from Cornell University, a former AAR fellow in the field of landscape architecture, who addressed "Opulent Waters: Landscape Architectural Displays of Water Wealth in Ancient Rome". Water and the display of power are presented in a book published at Cambridge titled "Gardens of the Roman Empire". Several case studies are featured therein, starting with Villa Arianna at Ancient StabiaeCastellammare di Stabia (near Vesuvius). The book analyses the implications of what was found there on water distribution in Rome. This belongs to the field of Landscape archaeology (published in Quaderni di studi pompeiani). There was a gentle slope for water in the ancient house. Another case study was Domus Tiberiana on Palatine Hill (with roof gardens). Hortae, the gardens of Rome's elite, were a kind of green belt around the city. Viridia was found on the porticus (on the hills, in the floodplain/campus: marshes and palace). Water was there firstly for land and production, and only secondly for entertainment purposes. Other examples included Templum Pacis, Templum Elagablus and Villa Borg, Germany, a reconstruction, as well as Palace of Kasyapa in Sri Lanka. Viridia was presented as a garden painting.

The last talk in this session was given by Paolo Squatriti from the University of Michigan, a historian who studied "Water Management in Medieval Italy". The breakdown of the Roman Empire resulted in land fragmentation in Italy. Given this context, the author wrote about peasants and social memory in a book published at Cambridge titled "Water and society in early medieval Italy", as well as in two others "Working with water in early medieval Europe technology and resource use" and "Nature's past" published at the university where the speaker works. First as the basis of research the findings of Karl August Wittvogel were introduced. Vatrita is a short valley between Maiale and Gran Sasso. In the 8th century it belonged to the Duke of Spoleto. Back then, Spoleto belonged to the reign of Longobards, the capital of which was Pavia, to which reference is made in the presentation in the context of privatisation. A second example is Bassa Milanese in the high Middle Ages. Today, there are rural parks here. Peasants near Pavia on the banks of Ticino are presented in the context of hydrological labour of rural communities on naviglio grande. Turning back to Wittvogel, this can be called hydraulic despotism.

\section{SECOND SESSION}

The second session was opened by Katherine Rinne from the California College of the Arts with a talk titled "Trickle Down Theory in Late Renaissance and Baroque Rome", which focused on the water supply of fountains in Rome and thus on water which flows continuously, and on how water is used. The speaker is an architect, director of Aquae Urbis Romae (waters of the city of Rome), a webbased project developed for 20 years (started in 1998) that features a cartographic resource for over 2800 years of Rome water history (http://www3.iath.virginia.edu/waters/). In 2010, a book titled "The Waters of Rome: Aqueducts, Fountains, and the Birth of the Baroque City" was published on this topic. After the Middle Ages came the Illuminism, and, with the discovery of manuscripts, the Popes wanted to renovate the aqueducts. However, the speaker focused on everyday life and utilitarian uses.

The second talk was given by Greg Aldrete from the University of Wisconsin, Green Bay, who took 
on "Floods in Ancient Rome: The Eternal City Goes Under". The speaker is a history scholar (archaeology). First, Greg Aldrete investigated flood marks for 33 floods, then went on with accounts on moving by boat and closed the presentation with a photo of a surviving Roman bridge in flood in 1937. The duration and extent of floods were shown. Floods affect different buildings in various ways. A photo shows the Roman forum during the flood in 1902, and another one the round temple in early $20^{\text {th }}$ century flood. Circus Maximus and similar Antique sites are situated in flood prone regions. Baths are not in flood prone regions, as they are more vulnerable, as shown on a map. A list of all the Domus in Rome was compiled. $85 \%$ were located on hills (out of almost 300). Roman AntiFlood strategies included: fill (raise ground levels), drain (sewers), divert (canal schemes), contain (embankments - concrete walls). Why didn't the Romans do more to prevent flooding? Factors reducing Rome's vulnerability are topography, construction methods, elite housing distribution, water supply system. In 1910, the Tiber gates were completed; they had started being built after the flood of 1870. In 1902, they still had gaps, this is how the photo of that year's flood is explained in response to a question from the audience.

The last talk in the session was given on "Fascism and the Pontine Marshes". The speaker is a professor of history and history of medicine. The research focused on $20^{\text {th }}$ century Italy. He talked about malaria. The Pontine Marshes are an area between Rome and the sea. The Fascists wanted to transform this area in a rural zone. A painting by A. Bocchi entitled Malaria is shown - this was the reason. Mussolini wanted to drain the Pontine Marshes. Hydrologically, the Pontine Marshes is a flood plain, very close to the sea level. Floods are seasonal. This was the largest project undertaken by fascists in the 1930s. The newspaper La Stampa writes "Pontine Marshes are Amazonia". The greatest massacre of trees in Modern Europe took place here. Littoria, building peripheral housing in this area was a great construction project. Continia, Aprilia, Cometia are some of the newly established localities. These are cities built for people to better live in but display fascist control and power. A demographic revolution took place in the Pontine
Marshes (it was necessary to have a family). Mussolini labelled himself Italy's greatest physician. The Marshes have been dried and converted into farmland.

\section{PANEL SESSION}

These two sessions were followed by a panel on Water Management, Climate Change (environment), and Landscape Design featuring Julia Czerniak (Syracuse University), Annalisa Metta (Università Roma Tre), Edoardo Croci (Università Bocconi, Milano) and Carlo Pignoloni (ENEL Green Power SpA), moderated by John Ochsendorf. The topics were resource consumption: plastic bottles, nexus of water and energy, but also climate change, landscape and how they overlap with policy. The speakers were four accomplished designers and practitioners who talked 10 minutes each.

The first speaker, Julia Cseniak, presented a symposium she organised on designing with water at AAR in autumn (https://www.aarome.org/ sites/default/files/pr_en/designing-water-

symposium.pdf, https://designingwater.org/). Some highlights of the presentations in the first session at the symposium are: by the landscape architecture professor at the ETH Zürich Christophe Girot: a point cloud animation and sound recording of glaciers melting, a Michigan university geotextile project, a network that supported the gardens of Versailles. The symposium tackled urgent issues in our geological age- the Anthropocene. During the second session, it was shown how design matters as we are facing these global concerns, for example contaminated water: flooding, droughts and impurity. We have too many storm surges in the New York area, too little water in places with unique geomorphologic characteristics (e.g. Tel Aviv innovatively retaining water on site), and finally too highly contaminated water in Chinese cities where there is a rich legacy of farming. The third session was about technology, e.g. advanced digital modelling that allows experimentation accompanied by a garden show in the opening night of the event, visiting iconic water projects in Europe through the eyes of a designer 1. Villa of Tiberius in Sperlonga, 2. Baroque fountains (Trevi) in Rome, 3. Bagnaia - failing hydraulics is a new narrative of 
temporality, 4-5. Geneve -"regreening" the river turned to channel because of farming and floods with jet d'eau, 6. Versailles - exploring the garden's underground hydraulics, 7. Deltaworks Zeeland in the Netherlands.

AnnaLisa Metta, the first ENEL Italian fellow at AAR, from the architecture department of Roma Tre University, showed Evanescence, water, besides flowing. Water and climate change - mostly floods. Poste Urban park Rome 2018-19 is an own design of the speaker, situated in Flaminio district, which was shown. The speaker also presented a book on the shape of water. Turning to issues related to climate change "When Rome would have gone Tunis" is her project at AAR tackling of global warming. Some related projects the speaker investigated are Mosbach and Rahm in Taiwan, "water and energy", Lanzarote, fog capture in Chile to harvest rain from the clouds.

Eduardo Croci, the third speaker, an environmental economist (Universita Bocconi GREEN Lombardia), talked about urban design and decarbonisation: urban population growth; the international framework for urban sustainability UN 2030 agenda for sustainable development 2015, UNFCCC COP21 Paris 2015, New Urban Agenda 2016 UN Habitat III Quito. Urban-rural interactions were discussed, as were greenhouse gas emissions: urban form and interactions with urban infrastructure, waste, potential of cities to contribute to global mitigation. Climate change-related risks cities are facing include rising temperatures, heatwaves, precipitation and storm impact, rising sea levels. Nature-based solutions (NBS)/green infrastructure (GI) can help against climate change via ecosystem services. The insurance value of NBS for increasing resilience was discussed: reducing damages in case of negative events, linkage between land, water and energy nexus OECD 2017; a resource-efficient, resilient, circular city.

The last speaker was Carlo Pignoloni, engineer on renewable energy with water. ENEL invests in green power around the world and in renewables in Italy: efficiency, green roofs. According to the speaker, renewables changed the world through their physical and social impact.

One of the questions was how many green roofs are needed to ensure water storing capacity. Annalisa highlighted the necessity to think globally and to act locally. Designers have to be involved in these problems.

\section{DISCUSSION}

The conference closed with a discussion and followed a chronology starting with the Romans. Some of the papers dealt with rural landscapes. The rights of citizens and societies were analysed in case of floods and Pontine Marshes, but also in terms of access to water. Water as a common infrastructure raises our sense of citizenship. Looking at trickle down water in Baroque - Trevi, villa d'Este, and rich people - we may conclude that there should be new patronage of water. Are some cities doing better than others? Yes, these are the smart, resilient cities. Rankings depend on indicators and weights. Some cities are doing very well (Barcelona, Milan, Vienna, Amsterdam), but they have to learn from each other. Network of cities in sustainability include e.g. ICLEI (International Council for Local Environmental Initiatives). Peer to peer experiences for learning include direct participation in city networks, definition of common standards, indicators, targets, as well as adaptation of solutions to specific contexts, e.g. for building over rivers. Let's reintroduce natural systems! 